\title{
The Behavioral Patterns of the Student in the Position of Peer-Jury in Landscape Design Studio
}

\author{
Rahman Tafahomi \\ Department of Architecture, the University of Rwanda, RWANDA \\ *e-mail: tafahomi@gmail.com
}

Received: 05 March 2021; Accepted: 25 July 2021; Published: 26 July 2021

To cite this article (APA): Tafahomi, R. (2021). The Behavioral Patterns of the Student in the Position of PeerJury in Landscape Design Studio. EDUCATUM Journal of Social Sciences, 7(2), 57-65. https://doi.org/10.37134/ejoss.vol7.2.6.2021

To link to this article: https://doi.org/10.37134/ejoss.vol7.2.6.2021

\begin{abstract}
Abstrak
Tujuan kajian ini adalah untuk menangani corak tingkah laku pelajar terhadap latihan bersama rakan sebaya dan hasil pembelajaran di studio reka bentuk landskap. Walaupun studio reka bentuk dijalankan berdasarkan hubungan jurulatih utama studio dengan pelajar, melalui kajian ini, ianya diubah melalui hubungan terhadap eksperimen kepada penilai rakan sebaya. Soal selidik Likert diaplikasikan untuk melihat pendapat pelajar semester akhir, data dianalisis melalui ujian analisis faktor SPSS. Dapatan analisis menunjukkan bahawa pelajar dapat menangani aspek latihan yang berkesan dalam lima kelompok termasuk komunikasi, interaksi, pembentangan, inovasi, dan interpretasi. Pelajar dapat belajar melalui penilai juri rakan sebaya untuk berkomunikasi dengan rakan sekelas berdasarkan komen, kritikan, dan cadangan bagi meningkatkan pembentangan yang lebih baik. Komen dari juri rakan sebaya sebagai idea reka bentuk bagi menghasilkan inovasi dalam konseptualisasi reka bentuk. Kesimpulannya, para pelajar dapat merancang gaya komunikasi mereka sendiri bersama rakan sebaya melalui tafsiran mengenai projek reka bentuk. Hasil latihan mengalihkan proses pembelajaran dari pengajar ke arah penilai rakan sebaya dan berpusatkan pelajar.
\end{abstract}

Kata kunci: Corak Tingkah Laku, Juri Rakan Sebaya, Hasil Pembelajaran, pembelajaran rakan sebaya, Ujian Likert, Analisis Fakta, Studio Reka Bentuk Landskap

\begin{abstract}
The aim of this paper is to address the behavioral patterns of the students in peer-jury exercise and the learning outcomes in the landscape design studio. Despite the design studios run based on the relation of the master of the studio with the students, changing this relationship to the peer-learners experiments through this research. A Likert questionnaire was applied to ask the opinion of the students at the end of the semester, the data analyzed through a factor analysis test in SPSS. The findings of the analysis identified that the students addressed effective aspects of the exercise in five clusters including communication, interaction, presentation, innovation, and interpretation. The students learn through peer-jury to communicate with classmates through comments, critics, and recommendations, which is improved presentations. The comments of the peer-jury as an idea of design result in innovation in the design conceptualization. In conclusion, the students design their own style of communication in the position of peer-jury through an interpretation of the design projects. The results of the exercise shift the learning process from the instructor toward the peer-students and the peer-learners.
\end{abstract}

Keywords: Behavioral Patterns, Peer-Jury, Learning Outcomes, peer-learning, Likert Test, Facto Analysis, Landscape Design Studio

\section{INTRODUCTION}

The architectural design studios are grounded on the plans of activities by the instructor as the master of atelier based on the apprenticeship style of training (D'Souza, 2007), which as a general view called 
an old tradition (Drexler, 1975; Garric, 2017). The instructor is taken into consideration as the source of knowledge to lead the students through architecture activities such as design exercises, disk critics, and evaluation. In this process, the students work individually or in a group based on the decision of the master of the studio to fulfil the design project in the studio. In fact, the learning process of the students is designed based on the connection with the master of the studio although the students have time to work individually on their project to fulfill the deliverables (Armstrong, 2016). In other words, it is supposed that the students follow the guidance of the instructor in terms of one-way effect from instructor to the students as a school of thought (Ročāne, 2015) although there are studies on the significance of the peer influences in the learning process (Lee, 2005; Woolfolk, 2016; Chinn, 2011; Seifert \& Sutton, 2009).

In fact, the architecture design studios run based on the guidance of the master of atelier (Doyle, 2016) in the department of architecture, and the roadmap of this person determines the quality, process, and scale of the project. Despite the new theories of education emphasized the students-center orientation in the educational process, seemingly, the architecture schools have included some trends to keep the traditional style of apprenticeship in the learning process (Ciravoğlu, 2014). However, educational guidelines recommended to the peer-student in terms of an alternative source of learning not only through peer-tutor but also through the peer-review (McClean \& Hourigan, 2013; Mulder, Pearce, \& Baik, 2014).

The crits (Critics) has been an essential part of the desk critics, presentation and the final exam in the architectural design studio. This activity called with a different name such as backbone (Uluoğlu, 2000), core part (Philippou, 2001), interaction (Williams \& Robert, 1997), evaluation, and critics in architecture (Frayling, 1993). The critic as a tradition has been applied by the instructors and the visiting juries for commenting on the architectural design project of the students in terms of formative and summative assessments. The critics from the lecturer and juries take into consideration as a formal way for evaluation and revision of the design project although critics from a peer assume an unofficial way of interaction (Moore \& Teather, 2013).

To cover the gap, this paper is going to explain the process of experimental activity in the landscape design studio to switch the position of the students to a peer-jury to evaluate the quality of the design and products of other students. To design the experiment, in the first session of the studio, the instructor asked the students to arrange groups for both the design project and the evaluation of other students' works. It was supposed that the students present their own progress report on the design project and then they evaluate works of other students groups in each session of the studio. Through this exercise is attempted to discover the level of the peer influences on the quality of the design project, communication, and presentation between the students. It is supposed that this activity could lead the students to critical thinking through criticizing the works of the other students to enhance the quality of their own design project.

\section{PRECEDENT STUDIES ON THE PEER-JURY ACTIVITY}

The studies discussed widely the peer activities, evaluation, and effects on the learning outcomes in different studies. For example, studies of McClean and Hourigan emphasized the high level of learning outcomes through peer-jury activities in the design studio (McClean \& Hourigan, 2013). Despite the studies mentioned that the peer-reviewing is tended to be appled in an informal procedure than formal (Moore \& Teather, 2013), the results of the peer-jury were effective in the formative assessment in higher education (Double, McGrane, \& Hopfenbeck, 2020) and the students were fulfilled with the result (Mulder, Pearce, \& Baik, 2014).

In addition, the study highlighted that peer-activity increased the level of the interaction of the students, which has improved the skills and learning outcomes (Greenwood, Maheady, \& Delquadri, 2002; Lee, 2005). The peer-review activity by the students was mentioned as the high level of autonomy in the education, which has resulted in independence to the learners' activities (Ion, Barrera-Corominas, \& 
Tomàs-Folch, 2016). In fact such an activity can target effective educational outcomes through a continuous exercise as a process than an event (Seifert \& Sutton, 2009). This educational outcome was analyzed in terms of the motivation of the students in the collaborative activity in the classroom (Williams \& Robert, 1997), in terms of the engagement of the students in the learning process (Chinn, 2011).

The studies pointed out the influences of peer-jury activity on challenging, critical thinking, and creative thinking. For example, Lang advocated critical thinking in two stages including divergent and convergent stages in the behavioral pattern of designers, which referred to the process of critical thinking and creative thinking (Lang, 1987). This process was facilitated by graphical techniques in design studio such as sketching, drawing, and design in the architectural products (Laseau, 2000; Lawson, 2005). In fact, the graphical techniques have been the most common tools for architectural students to transfer the idea into a design project in the process of presentation, communication and evaluation in terms of the application of skills in the learning process (Moreno, 2010).

The process of the influences in the learning process is one of the key questions in the studies. For example, Lee (2005) pointed out the effective level of the influences by the students in higher education that they learn both knowledge and skills in universities (Noah \& Abdul Aziz, 2020). Woolfolk revealed a set of the behavioral patterns that are constructed on the peer-influences among the students in the cultural background (Woolfolk, 2016) through effects on the subjectivity of the students (Lee, 2005). It means despite the $12 \mathrm{~K}$ students learnt some fashionable elements and styles (Collins \& Steinberg, 2006), the mindset of the students were engaged by the construction of character in higher education (Lee, 2005).

The study on the studio culture revealed that the students received many comments from other students in the peer-review activities to improve their design projects (Tafahomi, 2020). In fact, the students attempted to share the ideas in the conceptualization and the design process with other students directly and indirectly, which created clusters of the ideas and processes in the design studio (Tafahomi \& Nadi, 2016). It meant that the students changed the behavioral patterns through the educational instruction, process, objectives, and influencers to achieve the learning outcomes by the peer learning process (Orîndaru, 2015). The study highlighted that the students learn and apply different style of learning process even though they are not aware of that (Anas, Mohd Isa, Omar, Mohd Fatzel, \& Ghazali, 2021); however, they are in the process of learning.

As a summary, the studies on the peer influences highlighted that the students influence on each other in both educational and behavioral aspects although in higher education the influences were deeper and with high effects of the influenced by the influencer. Despite the students sharing their comments unofficially, changing the position of the students to an effective jury increase the process of the learning outcomes through commenting, which was mentioned in terms of peer-review, peer-tutor, and peerjury through critical thinking.

\section{METHODOLOGY AND MATERIALS}

The methodology of this paper was designed based on the quantitative method based using Likert questionnaire (Neuman, 2006; Frankfort-Nachmias, Nachmias, \& DeWaard, 2014), and qualitative methods for the interpretation of the results (Groat \& Wang, 2002; Krippendorff, 2003; Niezabitowska, 2018). The quantitative analysis attempted to extract the logic beyond the structure of the questions in a questionnaire technique (Meyers, Gamst, \& Guarino, 2012) although the application of this Likert questionnaire has been faced the critical view particularly the ratio between the question and the respondents (Hair, Black, Babin, \& Anderson, 2010). Despite the wide range of the statistical methods for the analysis of the Likert questionnaire introduced, the factor analysis applied to discover the effective factors in the questionnaire based on the students' selections. The factors were assumed in terms of the effective factors in the peer-jury activity. This purpose grounded on the restructuring of the 
data to a new format to discover the structural factors among other items (Brace, Kemp, \& Snelgar, 2006). In fact, the factor analysis applied for the reduction of a wide range of the variables based on the level of the internal correlation to highlight the underlying factors among other variables. Studies highlighted that the factor analysis test is more constructed based on the interpretive approach (Almquist, Ashir, \& Brännström, 2014).

In fact, the Likert questionnaire was designed to test the effects of the exercise on the learning outcomes of the students in terms of the effectiveness of delivery educational materials. The Likert questionnaire was applied for examination of the social interests and beliefs by researchers (Frankfort-Nachmias, Nachmias, \& DeWaard, 2014). Despite some critics on the reliability of the Likert questionnaire in the research (Joshi, Kale, Chandel, \& Pal, 2015), this technique is commonly applied in education research particularly in higher education (Meeks, et al., 2013; Xi, Yuan, YunQui, \& Chiang, 2017). To analyze the data, information inserted in the SPSS version 20 to create a databank for the analysis operation. In the continuum, the results are also interpreted through the interpretation techniques (Mugerauer, 1995; Graumann, 2002).

The structure of the questionnaire: the questionnaire consists of 30 questions although mentioned that the opinions were not limited to the questions and the students can add any self-designed questions, comments, and outputs to the questionnaire. The questionnaire is designed based on the five components which include the self-expression of the students, comments on the design process, comments on the design product, behavior of the Jury in the position, and approach of the jury. In this process, it was expected that the answers to those questions could bring into comprehension the perception of the students about the exercise. Despite the fact the clusters of the questions were clear in the first stage of the research, the questions arranged in an unstructured format.

Research process: the exercise designed based on the grouping of the students in the peer-presenter, peer-jury in the classroom. It was supposed that the students arrange and design their groups based on their interests. The groups of the students presented the landscape design project to one of the groups in the position of the jury for evaluation. The peer-jury presented their ideas and judgment through comments, discussion, and reciprocal dialogues. The position of the presenter-groups and the jurygroups changed systematically in each session of the studio to avoid any prearrangement in terms of evaluating the same group with the same jury. In this way, each group just one time presented and evaluated in each session.

It was supposed that the students learn from comments of peer-jury to improve the level of understanding, participation, and discussion in the duration of the studio. Therefore, the exercise of the student-presenter and peer-jury was consistent throughout the whole semester in the studio. At the end of the semester, they were asked to complete the questionnaire with the grading of the questions to express the effects of the exercise on the learning outcomes in the studio. The questionnaire distributed between the students in the last peer-review-jury activity to discover the feedbacks of the exercise on the perceptions, judgments, and evaluation of the students. All 20 students filled the questionnaire as an extra activity at the end of the official time of the studio. The data was inserted in SPSS for the factor analysis test.

Time and location: the exercise took the place in the first semester of 2019-2020 for 11 weeks as the official time of the academic calendar. The time of the studio and the activities were two times per week in the morning. The location of the activities was a fourth-year design studio in the department of architecture at the University of Rwanda.

\section{RESULTS}

The results of the factor analysis in SPSS illustrated that despite the fact that 88 per cent of the variables took the position in 11 components in the Total Variance Explained table, 58 per cent of the items were in the first five groups, which seemingly was the consequence of the low number of the variables than categories. With the remove of two outlier data through Outlier Detection, the per cent of the Variance 
achieved was 61.42, which can be included as an acceptable value. In addition, the items below the .5 was removed with the extraction option to emphasize the items that achieved at least more than 50 per cent of the participants' marks. Table 1 illustrates those groups of the items to discover the meaning of those factors based on the respondents' responses.

Table 1: The Factor Analysis Based on Five Factors

Rotated Component Matrix

\begin{tabular}{|c|c|c|c|c|c|}
\hline & \multicolumn{5}{|c|}{ Component } \\
\hline & 1 & 2 & 3 & 4 & 5 \\
\hline $\begin{array}{l}\text { Jury Challenged Me to Discuss more } \\
\text { Jury Remind me Lessons Learnt } \\
\text { Jury Pointed out the Missed Aspects } \\
\text { Jury Repeated Lessons Learnt } \\
\text { Jury Interacted in Positive way } \\
\text { Jury Helped me for Self-Expression } \\
\text { Jury Inspired Me } \\
\text { Jury Led Me to Improve the Design } \\
\text { The Exercise resulted in Face-to-Face } \\
\text { The Exercise resulted Class Interaction } \\
\text { Activity helped me Review on Lessons Learnt } \\
\text { The Exercise was a Professional Activities } \\
\text { The Exercise helped me for Self-Confident } \\
\text { The Exercise helped me in my Expression and Presentation } \\
\text { The Exercise was effective on the Precedents Analysis } \\
\text { The Exercise was effective on the Concept Generation } \\
\text { The Exercise was effective on the Team working } \\
\text { The Exercise was effective on the Other items } \\
\text { Jury Introduced New Idea } \\
\text { Jury Helped to cover the Missing Aspects } \\
\text { Jury Application New Idea } \\
\text { Jury Commented Polite and Respective } \\
\text { Jury Reinterpreted my presentation } \\
\text { Jury Interpreted my presentation }\end{array}$ & $\begin{array}{l}.748 \\
.741 \\
-.722 \\
.706 \\
-.662 \\
.524\end{array}$ & $\begin{array}{l}.799 \\
.733 \\
.672 \\
.662 \\
.659 \\
.657\end{array}$ & $\begin{array}{l}.775 \\
.741 \\
.650 \\
.627 \\
.572 \\
-.562\end{array}$ & $\begin{array}{l}.722 \\
-.676 \\
-.616\end{array}$ & $\begin{array}{r} \\
\\
.830 \\
.640 \\
.569\end{array}$ \\
\hline
\end{tabular}

Component one referred to those challenging aspects of the presentation for the students, which the jury groups reminded and repeated on the works of student-presents. Component two included some social interaction between students which inspired them for the conceptualization and designing process. The data in components three referred to the student presentation and communication, which resulted in helping the students to improve the self-confidence and self-expression. Components four referred to the analytical data that inspired the students for the design and architectural product, and components five referred to the approach of the interpretation and understanding of the jury about the presentation. Therefore, according to the factor analysis the principal components of the analysis listed in terms of communication, interaction, presentation, innovation, and interpretation skills, which students marked those items as the most effective factors in the exercise.

\section{INTERPRETATION OF THE RESULTS}

The students highlighted that communication is one of the important aspects of the design process to present, comment on, and evaluate the design project. The students demonstrated that the exercise has improved their communication skills by providing opportunities for self-presentation and project presentation. The exercise has also provided the chance for the students to comment on the presentation of other students through critical views, analysis, and evaluation. The data also revealed that the students believed that peer-jury communicated in a positive way to remind, repeat, and indicate the missing 
aspects of the design project. The positive communication created a sense of comfort for the students in communication with the peer-jury, which seemingly, they knew that they are students with the same level of experience and knowledge.

The exercise created an open forum for an official and transparent discussion and interaction between the students in the studio. The students participated in the discussion through the peer-jury or the rest of the class to form social interaction through face-to-face dialogue. Perhaps, for this reason, this activity inspired them to apply the comments in the design process for improving the architectural design products.

Both communication and interaction with the peer-jury were resulted in the gradual improvement of presentation skills by the students. The students mentioned that they were in a self-confident mood in the presentation times and they expressed and presented the project as a result of the team work. Seemingly, the team work did not refer to just the students-presenter but the peer-jury activities. In fact, both student-presenter and peer-jury collaborated simultaneously to enhance the quality level of the design projects, which revealed the effectiveness of the team work. Therefore, the presentation and feedback from the peer-jury helped the students for the concept generation through communication and interaction components.

Innovation was one of the important aspects of the activity through an interplay between the communication, interaction and presentation to lead the students for personalization of the ideas in the design activities. The interaction through the challenging of the design ideas of other presenters in the exercise led the students for inspiration to transform the ideas for their own design ideas. This new set of the idea was applied in the revising of the process of design, developing the analysis, and generating new concept to represent the idea in the innovation aspect of design. In fact, the design process addressed both the design process and design product as a continuous activity among the groups of the students to improve the design results through an interchanging of the idea.

The exercise provided an opportunity for the students to interpret the design projects not only as an architectural idea to discuss and evaluate but also a system of understanding thoughts through a continuous dialogue between the students. According to the meaning of the interpretation in terms of bringing into understand, apparently the exercise enhanced the level of understanding of the students. The students highlighted what they expected from a jury member by indicating the questions. In detail, the students had the experience about the process of the evaluation and quality of comments in both desk critics in terms of the formative assessment and final exam presentation as summative assessment by the instructors. The students advocated their specific style of evaluation in terms of positive, polite, and friendly dialogue. Despite the results did not indicate any wrong experiences with the jury, the emphasis on those positive aspects of the peer-jury revealed that other aspects of the interaction existed in the department, which requires to be taken into consideration.

\section{DISCUSSION}

The results of the research demonstrated that the students progressed to the stage of self-confidence and self-expression in communication, which in the previous study was highlighted in terms of the autonomy of the students (Ion, Barrera-Corominas, \& Tomàs-Folch, 2016). In addition, the outputs of the research supported the theory of the peer-activities, which emphasized the improvement of the skills through peer activities (Greenwood, Maheady, \& Delquadri, 2002). The peer-jury increased the collaborative activities (Williams \& Robert, 1997) in the studio, which resulted in more engagement of the students with a different possibility and style in design (Chinn, 2011). In fact, the collaborative activities constructed specific culture in the studio as peer-effects, which was discussed by Lee and Woolfolk in terms of peer-influences (Lee, 2005; Woolfolk, 2016).

The results of the study stressed that the students learnt effectively to harmonize the idea and the design into a project for presentations, which already emphasized in previous studies (Tafahomi \& Nadi, 2016; Tafahomi, 2020). The students enhanced the quality of the presentation such as graphical abilities, ideas, 
and the process of changing the idea into conceptual elements for design (Lawson, 2005; Laseau, 2000). This aspect of the learning outcomes supported the achievement of Orindaru in terms of changing of behavioral pattern of the learners through a peer-learning process (Orîndaru, 2015).

The students developed their idea for the design project in the exercise smoothly. This achievement was similar to the graphical theories, which emphasized the behaviors of the designers in the design process (Lang, 1987; Laseau, 2000; Lawson, 2005). The students applied the graphical techniques in terms of skills in the learning process, which highlighted by Morene (2010), to personalize the learning outputs into design form.

The finding of the research was in line with the paradigm-shift from the teacher-center to student-center, in which the outputs of the data revealed that the students were satisfied with the learning outcomes and the effects of the exercise (Mulder, Pearce, \& Baik, 2014). In addition, the students were comfortable communicating with the peer-jury to receive feedback in the process of the architectural products, which Double and colleges emphasized (Double, McGrane, \& Hopfenbeck, 2020). The exercise affected the process of learning by changing the students' character in terms of engagement of the mind of the students in the learning process (Lee, 2005), which emphasized by Seifert and Sutton in terms of learning process approach than an event (Seifert \& Sutton, 2009).

\section{CONCLUSION}

Engagement of the students in the learning process could change the position of the students from an observer to an effective influencer in the design studio. This experimental research engages the students in the position of the critical jury to discover the consequences of the activity and to share the results of the exercise as the lesson learnt. In fact, a new generation of students and learning approaches in institutions require exercise, research, and experiment activities to develop an accurate road map for teaching and learning in higher education. The exercise includes positive effects to enhance the level of the students from a presenter into the level of the peer-jury to facilitate the process of peer-learning through the peer-communication. A Likert questionnaire and the Factor Analysis present the important achievement of the exercise through analysis and interpretation.

The students demonstrate that they take seriously the responsibility in the position of the critical jury. The results of the research identified that the students design their style for the communication and interaction in the position of jury although they observed critics activities in the desk-crits and the final exams by the instructors. This enhancement of the level of the students from the receiver of comments from the instructor to the jury to make comments on the design products of other students is a step forward to orient the teaching activity from teacher-center to student-center.

The students highlight through the questionnaire that the exercise was effective in the design process and the quality of the final project. In fact, the engagement of the students in the evaluation process provides an opportunity for them to share ideas, discuss the design, and comment on the project, which is created an advantage to enhance the learning outcomes. Those learning outcomes are presented through factor analysis, which is titled with the header as communication, interaction, presentation, innovation, and interpretation. The interpretation of the design' outputs in the exercise demonstrates the high level of understanding, attempt to understand and listen to other understanding about own project. The communication and interaction between the students construct as a platform for dialogue and discourse about the architectural design project. It means that the students endeavor to move further from self-expression and understanding to the level of comprehension through interpretation of the project presentations in the design studio. 


\section{REFERENCES}

Almquist, Y. B., Ashir, S., \& Brännström, L. (2014). A guide to quantitative methods. Stockholm: Stockholm University, Sweden. Retrieved from www.chess.su.se/methods

Anas, N., Mohd Isa, N., Omar, N., Mohd Fatzel, F. H., \& Ghazali, Z. M. (2021). The Relationship Between Students' Learning Styles and Academic Performance: Final Year Accounting Students. EDUCATUMJournal of Social Science (EJOSS), 7(1), 1-9. doi:10.37134/ejoss.vol7.1.1.2021

Armstrong, C. D. (2016). French Architectural Thought and the Idea of Greece, Eighteenth- and NineteenthCentury French Views on Greek Architecture. In M. M. Miles, A Companion to Greek Architecture, (pp. 487-508). New York: John Wiley \& Sons, Inc.

Brace, N., Kemp, R., \& Snelgar, R. (2006). SPSS for Psychologists. Basingstoke, UK: Palgrave Macmillan.

Chinn, C. A. (2011). Educational Psychology: Understanding Students' Thinking. Rutgers University: New Jersey.

Ciravoğlu, A. (2014). Notes on architectural education: An experimental approach to design studio. Procedia Social and Behavioral Sciences 152 ( 2014 ) 7 - 12, 152, 7-12. doi:10.1016/j.sbspro.2014.09.146

Collins, W. A., \& Steinberg, L. (2006). Adolescent development in interpersonal context. In W. Damon, R. Lerner ,\& N. Eisenberg, Handbook of child psychology: Vol. 3. Social, emotional, and personality development (pp. 1003-1067)). New York, NY: Wiley.

D'Souza, N. (2007). Design Intelligences: A Case for Multiple Intelligences in Architectural Design. International Journal of Architectural Research, 1(2), 15-43.

Double, K. S., McGrane, J. A., \& Hopfenbeck, T. N. (2020). The Impact of Peer Assessment on Academic Performance: A Meta-analysis of Control Group Studies. Educational Psychology Review, 32, 481-509. doi:10.1007/s10648-019-09510-3

Doyle, S. (2016). Bringing Bauhaus Back: Digital Architecture + Contemporary Craft. Architecture/Practice: Pre-Modern Training For a Postmodern Practice (pp. 1-7). Iowa: the Architecture at Iowa State University Digital Repository.

Drexler, A. (1975). THE ARCHITECTURE OF THE ECOLE DES BEAUX-ARTS. New York: The Museum of Modern Art.

Frankfort-Nachmias, C., Nachmias, D., \& DeWaard, J. (2014). Research Methods in the Social Sciences (8 ed.). New York: SAGE Publisher Ink.

Frayling, C. (1993). Research in Art and Design. Royal College of Art Research Paper, 1(1), 1-5.

Garric, J.-P. (2017). The French Beaux-Arts. In M. Bressani, \& C. Contandriopoulos, The Companions to the History of Architecture, Volume III, Nineteenth-Century Architecture, Part I. Historicism, the BeauxArts, and the Gothic (pp. 1-15). New York: John Wiley \& Sons, Inc.

Graumann, C. F. (2002). The Phenomenological Approach to People-Environment Studies. In R. B. BECHTEL, \& A. CHURCHMAN , HANDBOOK OF ENVIRONMENTAL PSYCHOLOGY (pp. 95-113). New York: John Wiley \& Sons, Inc.

Greenwood, C. R., Maheady, L., \& Delquadri, J. (2002). Classwide Peer Tutoring programs. In M. R. Shinn, H. M. Walker, \& G. Stoner, Interventions for academic and behavior problems II: Preventive and remedial approaches (pp. 611-649). Bethesda, MD.

Groat, L., \& Wang, D. (2002). Architectural Research Methods. New York: John Wiley \& Sons INC.

Hair, J. F., Black, W. C., Babin, B. K., \& Anderson, R. E. (2010). Multivariate Data Analysis. New York: Pearson,.

Ion, G., Barrera-Corominas, A., \& Tomàs-Folch, M. (2016). Written peer-feedback to enhance students' current and future learning. International Journal of Educational Technology in Higher Education, 13(15), 111. doi:10.1186/s41239-016-0017-y

Joshi, A., Kale, S., Chandel, S., \& Pal, D. K. (2015). Likert Scale: Explored and Explained. British Journal of Applied Science \& Technology, 7(4), 396-403.

Krippendorff, K. H. (2003). Content Analysis: An Introduction to Its Methodology (2 ed.). New York: Sage Publications.

Lang, j. (1987). Creating Architectural Theory: The Role of the Behavioral Sciences in Environmental Design . New Your: Van Nostrand Reinhold.

Laseau, P. (2000). Graphic Thinking for Architects and Designers (3th ed.). New York: Wiley.

Lawson, B. (2005). How Designers Think: The Design Process Demystified (4 ed.). Oxford: Oxford Press.

Lee, S. W. (2005). Encyclopedia of school psychology. Thousand Oaks, California: Sage Publications.

McClean, D., \& Hourigan, N. (2013). Critical Dialogue in Architecture Studio: Peer Interaction and Feedback. Journal for Education in the Built Environment, 8(1), 35-57. doi:10.11120/jebe.2013.00004

Meeks, M. D., Knotts, T. L., James, K. D., Williams, F., Vassar, J. A., \& Wren, A. O. (2013). The Impact of Seating Location and Seating Type on Student Performance. Education Science, 3, 375-386. 
Meyers, L. S., Gamst, G., \& Guarino, A. J. (2012). Applied Multivariate Research: Design and Interpretation . New York: SAGE.

Moore , C., \& Teather, S. (2013). Engaging students in peer review: Feedback as learning. Issues in Educational Research,, 23(2), 196-211. Retrieved from https://ro.ecu.edu.au/ecuworks2013/9

Moreno, R. (2010). Educational Psychology. Hoboken, NJ: John Wiley \& Sons, Inc.

Mugerauer, R. (1995). Interpreting Environments: Tradition, Deconstruction, Hermeneutics. Texas: University of Texas.

Mulder, R. A., Pearce, J. M., \& Baik, C. (2014). Peer review in higher education: Student perceptions before and after participation. Active Learning in Higher Education, 15(2), 157-171. doi:10.1177/1469787414527391

Neuman, L. W. (2006). Social Research Methods: Qualitative and Quantitative Approaches. New York: Pearson Education.

Niezabitowska, E. D. (2018). Research Methods and Techniques in Architecture. New York: Routledge.

Noah, J. B., \& Abdul Aziz, A. B. (2020). A Systematic review on soft skills development among university graduates. EDUCATUM - Journal of Social Science (EJOSS), 6(1), 43-58. Retrieved from https://ejournal.upsi.edu.my/index.php/EJOSS/article/view/3485

Orîndaru, A. (2015). Changing Perspectives on Students in Higher Education. In P. E. Finance (Ed.), 22nd International Economic Conference - IECS 2015 "Economic Prospects in the Context of Growing Global and Regional Interdependencies”, IECS 2015. 27, pp. 682 - 691. Elsevier.

Philippou, S. (2001). On a Paradox in Design Studio Teaching or the Centrality of the Periphery. Architectural Education Exchange Architectural Educators: Responding to Change (pp. 2-13). Cardiff : Cardiff University, LTSN Center for Education in the Built Environment,.

Ročāne, M. (2015). The Significance of Teacher'S Beliefs in the Learning Process. Society, Integration, Education, 2, 165-177. doi:10.17770

Seifert, K., \& Sutton, R. (2009). Educational Psychology. Zurich, Switzerland: Global Text .

Tafahomi, R. (2020). Educational Outcome of Students' Group-Table Arrangement for Collaboration in Architectural Thesis Studio. LWATI: A Journal of Contemporary Research, 17(2), 22-46.

Tafahomi, R., \& Nadi, R. (2016). Modelling of thought in creation designing concept in urban design studio training. Prime Research on Education (PRE), 5(2), 821-828.

Uluoğlu, B. (2000). Design knowledge communicated in studio critiques. Design Studies, 2, 33-58.

Williams, M., \& Robert, L. B. (1997). Psychology for Language Teachers. Cambridge: Cambridge University Press.

Woolfolk, A. (2016). Educational Psychology. Boston: Pearson.

Xi, L., Yuan, Z., YunQui, B., \& Chiang, F.-K. (2017). An Investigation of University Students' Classroom Seating Choices. Journal of Learning Spaces, 6(3), 13-22. 